\title{
TOURISM FUNCTION AS AN ELEMENT OF REGIONAL COMPETITIVENESS
}

\author{
RENATA KRUKOWSKA, ANDRZEJ ŚWIECA \\ Maria Curie-Skłodowska University, Faculty of Earth Sciences and Spatial Management, \\ Department of Regional Geography and Tourism, Lublin, Poland
}

\author{
Mailing address: Renata Krukowska, UMCS, WNoZiGP, Department of Regional Geography and Tourism, \\ 2d Kraśnicka Ave., 20-718 Lublin, tel.: +48 81 5376852, fax: +48 81 5376862, e-mail: renata.krukowska@umcs.pl
}

\begin{abstract}
Introduction. Regions can gain a competitive advantage in different ways, among others by making rational use of their resources in creating regional tourism products. Among these resources, what is of major importance, apart from having natural and cultural resources, is the tourist accommodation offered, which not only makes it possible to increase tourist traffic in the region but can also give it a competitive advantage over other regions. The accommodation and the tourist traffic recorded there can serve as indicators of the level of the development of the tourism function of a region and its dynamics. The aim of the current study is to determine, describe, and analyse the nature of the changes in the tourism function of all sixteen provinces in Poland. Material and methods. The study used indices based on the size and type of the accommodation and the volume of tourist traffic. Statistical data for the years 2000-2015 concerning the size of the tourist accommodation as well as the types of facilities and their occupancy by tourists were obtained from the official publications of the Polish central statistical office. The tourism function indices for Poland and particular provinces were calculated based on data for 2000 and 2015. The results obtained made it possible to identify trends in the increases or decreases in the tourist accommodation capacity and tourist traffic in the facilities and to estimate the changes in the tourism function based on this analysis. Conclusions. The data that were collected and processed made it possible to determine the regional structure of the tourist accommodation offered as well as the level of its occupancy. In general, the largest concentration of tourist accommodation was found in regions of high natural and cultural value (the Zachodniopomorskie, Pomorskie, Małopolskie, and Dolnośląskie Provinces). According to the values of the tourism function indices, the following provinces were in the most favourable situation: Zachodniopomorskie, Małopolskie, and Pomorskie (with a Schneider index exceeding 100 and a Charvat index exceeding 300). A relatively high level of the development of the tourism function was also noted for the Dolnośląskie Province (with the aforementioned indices exceeding the values of 90 and approximately 250, respectively). The four provinces listed above also distinguished themselves when it comes to the values of the Defert index (above 100), that is the number of tourists relative to the surface. The provinces whose tourism function was the least developed were the Opolskie and Lubelskie Provinces (with a Schneider index below 80, a Charvat index below 80, and a Defert index below 30).
\end{abstract}

Key words: tourist accommodation, province, tourism function

\section{Introduction}

In contemporary models of socio-economic development, competition is regarded as a driver of the economy. Competitiveness became particularly important in tourism in the second half of the 20th century owing to better social-spatial mobility and the increased economic role of tourism-related expenses in regions visited by tourists, which are most often conceptualised as systems (administrative division units, such as cities and regions) functioning in particular geographical areas [1, 2, 3, 4]. For administrative division units, the tourism function is treated as an objective measure of the space where there is tourist activity and where tourism-related infrastructure of various size has been created [5]. Owing to the fact that the space is used simultaneously by tourists and economic entities operating in a given area, particular areas can be regarded as having individual tourism functions [6].

Many authors have endeavoured to define and measure the tourism function. Scholars from different disciplines often treat it as one of the most important factors determining functional changes in urban and rural areas. The literature offers many definitions of the tourism function, and some authors make a distinction between a geographical and economic perspective [7].

Taking a geographical point of view, Matczak [8] defines the tourism function as the entire socio-economic activity in a certain area oriented towards providing services to tourists, thanks to which particular types of their needs can be satisfied. The issue of analysing the level of the development of the tourism function in different spatial entities has been addressed, among others, by Fischbach [9], Derek [10], Pytel [11], Gołembski (ed.) [12], Więcław-Michniewska [13], Szromek [14], Durydiwka [15, 16], and Piotrowski [17]. The methods typically used in such research are index methods. These were applied, among others, by Warszyńska [18], Chudy-Hyski [19], Żek [20], Krukowska [21], Pytel [11], Majewska [22], Spychała and Graja-Zwolińska [23], Szromek [14], as well as Kiniorska and Partyka [7].

If the tourism function is understood as the role played by a given area in a larger spatial entity [23], each administrative division unit of a country (including provinces) can be characterised with respect to the level of the development of this function and its changes over time [22]. 
The aim of the current study is to determine, describe, and analyse the nature of the changes in the tourism function of all sixteen provinces in Poland. This function is used to evaluate the level of the competitiveness of the provinces.

\section{Material and methods}

In order to determine the current state as well as the dynamics and direction of the changes in the tourism function of the provinces, we used index methods, including three supply indices and three demand indices (Tab. 1). The supply indices used in the study, which were related to infrastructure, were the tourist accommodation density index, the tourist accommodation development index, and the Baretje-Defert index. The demand indices, measuring the volume of tourist traffic, were the Defert index, the Schneider index, and the Charvat index (Tab. 1).

Table 1. Descriptions and formulae of tourism function indices used in the study

\begin{tabular}{|c|c|c|}
\hline Index name & Description & Formula \\
\hline \multirow{2}{*}{$\begin{array}{l}\text { Tourist accom- } \\
\text { modation density } \\
\text { index }\end{array}$} & \multirow{2}{*}{$\begin{array}{l}\text { Indicates number of } \\
\text { guest beds per } 1 \mathrm{~km}^{2} \text { of } \\
\text { area surface }\end{array}$} & number of guest beds \\
\hline & & area surface \\
\hline \multirow{2}{*}{$\begin{array}{l}\text { Tourist accommo- } \\
\text { dation develop- } \\
\text { ment index }\end{array}$} & \multirow{2}{*}{$\begin{array}{l}\text { Indicates number of tour- } \\
\text { ists using accommoda- } \\
\text { tion per guest bed }\end{array}$} & $\begin{array}{c}\text { number } \\
\text { of accommodation users }\end{array}$ \\
\hline & & number of guest beds \\
\hline \multirow{2}{*}{$\begin{array}{l}\text { Baretje-Defert } \\
\text { index }\end{array}$} & \multirow{2}{*}{$\begin{array}{l}\text { Measures develop- } \\
\text { ment of tourism-related } \\
\text { infrastructure; indicates } \\
\text { number of guest beds } \\
\text { per } 100 \text { inhabitants }\end{array}$} & $100 \times$ number of guest beds \\
\hline & & number of inhabitants \\
\hline \multirow[t]{2}{*}{ Defert index } & \multirow{2}{*}{$\begin{array}{l}\text { Measures volume/con- } \\
\text { gestion of tourist traffic; } \\
\text { indicates number of } \\
\text { tourists using accommo- } \\
\text { dation per } 1 \text { km² of area } \\
\text { surface }\end{array}$} & $\begin{array}{c}\text { number } \\
\text { of accommodation users }\end{array}$ \\
\hline & & area surface \\
\hline \multirow[t]{2}{*}{ Schneider index } & \multirow{2}{*}{$\begin{array}{l}\text { Measures volume/inten- } \\
\text { sity of tourist traffic; indi- } \\
\text { cates number of tourists } \\
\text { using accommodation } \\
\text { per } 100 \text { inhabitants }\end{array}$} & $\begin{array}{l}100 \times \text { number } \\
\text { of accommodation users }\end{array}$ \\
\hline & & number of inhabitants \\
\hline \multirow[t]{2}{*}{ Charvat index } & \multirow{2}{*}{$\begin{array}{l}\text { Measures intensity of } \\
\text { tourist traffic; indicates } \\
\text { number of overnight } \\
\text { stays per } 100 \text { inhabitants }\end{array}$} & $\begin{array}{c}100 \times \text { number } \\
\text { of overnight stays }\end{array}$ \\
\hline & & number of inhabitants \\
\hline
\end{tabular}

Source: our previous work based on Szromek [14].

The indices listed above are commonly used in studies which address issues related to the tourism function. In the current study, the indicators of the tourism function were calculated based on data recorded by the Polish central statistical office (Statistics Poland, GUS), in the years 2000 and 2015.

Based on the results obtained and on the criteria adopted, we ranked the sixteen provinces in Poland according to how dynamic the changes in their tourism function were.

\section{Results}

Concentration of tourist accommodation in Poland

Accommodation is an element of the tourism infrastructure, which, in principle, is used only by tourists and whose size and state have a direct influence on the development of tourism in the local area [8]. Along with the tourism-related values and attractions, it is a basis for creating the tourism product of a given area that is a tourist destination [26]. It is also an important factor for economic competitiveness [2].

According to the data of the central statistical office in Poland (Statistics Poland, GUS), towards the end of 2015, there were 10,024 tourist accommodation facilities in Poland, offering 710,274 beds (Tab. 2).

Table 2. Number of accommodation facilities and guest beds in Polish provinces in 2000 and 2015

\begin{tabular}{|c|c|c|c|c|c|}
\hline \multirow[b]{2}{*}{ Province } & \multirow[b]{2}{*}{ Year } & \multicolumn{2}{|c|}{ Number of facilities } & \multicolumn{2}{|c|}{ Number of guest beds } \\
\hline & & $\begin{array}{c}\text { All } \\
\text { facilities }\end{array}$ & $\begin{array}{c}\text { Hotel } \\
\text { facilities }\end{array}$ & $\begin{array}{c}\text { All } \\
\text { facilities }\end{array}$ & $\begin{array}{c}\text { Hotel } \\
\text { facilities }\end{array}$ \\
\hline \multirow{2}{*}{ Dolnośląskie } & 2015 & 867 & 374 & 60,147 & 33,151 \\
\hline & 2000 & 880 & 201 & 54,315 & 14,169 \\
\hline \multirow{2}{*}{$\begin{array}{l}\text { Kujawsko- } \\
\text { Pomorskie }\end{array}$} & 2015 & 367 & 164 & 28,515 & 11,217 \\
\hline & 2000 & 431 & 59 & 29,960 & 4,028 \\
\hline \multirow{2}{*}{ Lubelskie } & 2015 & 369 & 149 & 21,848 & 8,634 \\
\hline & 2000 & 476 & 49 & 24,312 & 3,246 \\
\hline \multirow{2}{*}{ Lubuskie } & 2015 & 288 & 131 & 18,570 & 7,372 \\
\hline & 2000 & 313 & 57 & 19,813 & 3,397 \\
\hline \multirow{2}{*}{ Łódzkie } & 2015 & 352 & 206 & 23,128 & 14,668 \\
\hline & 2000 & 245 & 68 & 23,705 & 4,974 \\
\hline \multirow{2}{*}{ Małopolskie } & 2015 & 1,448 & 467 & 90,304 & 42,038 \\
\hline & 2000 & 1,055 & 197 & 66,602 & 18,567 \\
\hline \multirow{2}{*}{ Mazowieckie } & 2015 & 486 & 308 & 48,982 & 37,539 \\
\hline & 2000 & 313 & 88 & 32,994 & 13,824 \\
\hline \multirow{2}{*}{ Opolskie } & 2015 & 168 & 83 & 9,401 & 4,170 \\
\hline & 2000 & 104 & 28 & 6,391 & 1,475 \\
\hline \multirow{2}{*}{ Podkarpackie } & 2015 & 527 & 208 & 28,711 & 12,015 \\
\hline & 2000 & 427 & 71 & 22,269 & 4,235 \\
\hline \multirow{2}{*}{ Podlaskie } & 2015 & 269 & 89 & 13,465 & 6,116 \\
\hline & 2000 & 255 & 29 & 16,107 & 2,311 \\
\hline \multirow{2}{*}{ Pomorskie } & 2015 & 1,512 & 319 & 101,739 & 26,166 \\
\hline & 2000 & 977 & 118 & 97,414 & 10,256 \\
\hline \multirow{2}{*}{ Śląskie } & 2015 & 633 & 306 & 45,884 & 26,664 \\
\hline & 2000 & 536 & 146 & 42,568 & 13,086 \\
\hline \multirow{2}{*}{ Świętokrzyskie } & 2015 & 246 & 132 & 16,101 & 8,563 \\
\hline & 2000 & 162 & 35 & 9,842 & 2,037 \\
\hline \multirow{2}{*}{$\begin{array}{l}\text { Warmińsko- } \\
\text { Mazurskie }\end{array}$} & 2015 & 492 & 189 & 40,022 & 16,097 \\
\hline & 2000 & 589 & 106 & 48,943 & 8,641 \\
\hline \multirow{2}{*}{ Wielkopolskie } & 2015 & 701 & 345 & 42,854 & 22,782 \\
\hline & 2000 & 680 & 107 & 42,708 & 8,503 \\
\hline \multirow{2}{*}{$\begin{array}{l}\text { Zachodnio- } \\
\text { pomorskie }\end{array}$} & 2015 & 1,299 & 253 & 120,603 & 24,363 \\
\hline & 2000 & 1,183 & 90 & 130,389 & 7,531 \\
\hline \multirow{2}{*}{ POLAND } & 2015 & 10,024 & 3,723 & 710,274 & 301,555 \\
\hline & 2000 & 8,626 & 1,449 & 668,332 & 120,280 \\
\hline
\end{tabular}

Source: Statistics Poland [24, 25].

The tourist accommodation was not evenly distributed (Fig. 1) since almost half of the accommodation facilities (42.5\%) and guest beds (44.0\%) were concentrated in three provinces, that is the Pomorskie (15.1\% and $14.3 \%$, respectively), Małopolskie (14.4\% and 12.7\%), and Zachodniopomorskie (13.0\% and 17.0\%) Provinces. The absolute figures for these provinces were 4,259 facilities and 312,646 guest beds (Tab. 2). 


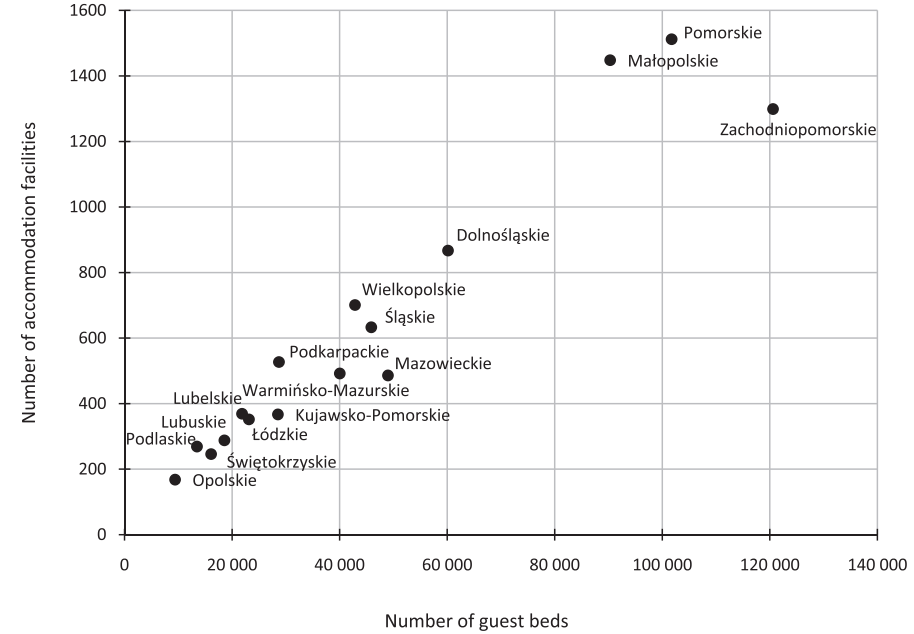

Figure 1. Number of accommodation facilities and guest beds in Polish provinces in 2015
In order to investigate variations in the concentration of tourist accommodation in terms of the beds offered to tourists, the number of guest beds per 100 inhabitants (Baretje-Defert index) and per $1 \mathrm{~km}^{2}$ (tourist accommodation density index) were calculated for each of the provinces. The results of these calculations are shown in Table 3 and Figures 2 and 3.

The Baretje-Defert index, which takes into account the number of inhabitants, showed that in 2015, there was a sevenfold difference between the extreme values found for the provinces (the Zachodniopomorskie Province had 7.1 guest beds while the Mazowieckie, Łódzkie, and Opolskie Provinces had approximately 1 guest bed per 100 inhabitants). The values for eleven provinces did not match the national average, which was 1.8 guest beds per 100 inhabitants (Tab. 3, Fig. 2).

Table 3. Indices measuring the level of tourism infrastructure development in Polish provinces in 2000 and 2015

\begin{tabular}{|c|c|c|c|c|c|c|c|}
\hline \multirow{2}{*}{ Province } & \multirow[t]{2}{*}{ Year } & \multicolumn{2}{|c|}{ Baretje-Defert index } & \multicolumn{2}{|c|}{$\begin{array}{l}\text { Tourist accommodation density } \\
\text { index }\end{array}$} & \multicolumn{2}{|c|}{$\begin{array}{c}\text { Tourist accommodation } \\
\text { development index }\end{array}$} \\
\hline & & All facilities & Hotel facilities & All facilities & Hotel facilities & All facilities & Hotel facilities \\
\hline \multirow{2}{*}{ Dolnośląskie } & 2015 & 2.1 & 1.1 & 3.0 & 1.7 & 43.6 & 60.2 \\
\hline & 2000 & 1.8 & 0.5 & 2.7 & 0.7 & 28.1 & 50.7 \\
\hline \multirow{2}{*}{ Kujawsko-Pomorskie } & 2015 & 1.4 & 0.5 & 1.6 & 0.6 & 37.0 & 66.9 \\
\hline & 2000 & 1.4 & 0.2 & 1.7 & 0.2 & 19.2 & 65.0 \\
\hline \multirow{2}{*}{ Lubelskie } & 2015 & 1.0 & 0.4 & 0.9 & 0.3 & 36.4 & 67.9 \\
\hline & 2000 & 1.1 & 0.2 & 1.0 & 0.1 & 21.2 & 64.1 \\
\hline \multirow{2}{*}{ Lubuskie } & 2015 & 1.8 & 0.7 & 1.3 & 0.5 & 33.2 & 63.2 \\
\hline & 2000 & 1.9 & 0.3 & 1.4 & 0.2 & 24.3 & 71.9 \\
\hline \multirow{2}{*}{ Łódzkie } & 2015 & 0.9 & 0.6 & 1.3 & 0.8 & 55.4 & 72.8 \\
\hline & 2000 & 0.9 & 0.2 & 1.3 & 0.3 & 22.4 & 59.2 \\
\hline \multirow{2}{*}{ Małopolskie } & 2015 & 2.7 & 1.3 & 6.0 & 2.8 & 45.1 & 70.1 \\
\hline & 2000 & 2.1 & 0.6 & 4.4 & 1.2 & 29.6 & 51.8 \\
\hline \multirow{2}{*}{ Mazowieckie } & 2015 & 0.9 & 0.7 & 1.4 & 1.1 & 83.9 & 99.7 \\
\hline & 2000 & 0.6 & 0.3 & 0.9 & 0.4 & 49.0 & 87.3 \\
\hline \multirow{2}{*}{ Opolskie } & 2015 & 0.9 & 0.4 & 1.0 & 0.4 & 35.0 & 53.7 \\
\hline & 2000 & 0.6 & 0.1 & 0.7 & 0.2 & 22.3 & 60.9 \\
\hline \multirow{2}{*}{ Podkarpackie } & 2015 & 1.4 & 0.6 & 1.6 & 0.7 & 33.4 & 55.9 \\
\hline & 2000 & 1.0 & 0.2 & 1.2 & 0.2 & 25.8 & 55.9 \\
\hline \multirow{2}{*}{ Podlaskie } & 2015 & 1.1 & 0.5 & 0.7 & 0.3 & 45.0 & 75.8 \\
\hline & 2000 & 1.3 & 0.2 & 0.8 & 0.1 & 24.2 & 64.6 \\
\hline \multirow{2}{*}{ Pomorskie } & 2015 & 4.4 & 1.1 & 5.6 & 1.4 & 24.0 & 60.2 \\
\hline & 2000 & 4.4 & 0.5 & 5.3 & 0.6 & 13.5 & 52.2 \\
\hline \multirow{2}{*}{ Ślaskie } & 2015 & 1.0 & 0.6 & 3.7 & 2.2 & 46.8 & 60.7 \\
\hline & 2000 & 0.9 & 0.3 & 3.5 & 1.1 & 30.4 & 49.4 \\
\hline \multirow{2}{*}{ Świętokrzyskie } & 2015 & 1.3 & 0.7 & 1.4 & 0.7 & 32.2 & 49.1 \\
\hline & 2000 & 0.7 & 0.2 & 0.8 & 0.2 & 26.9 & 69.8 \\
\hline \multirow{2}{*}{ Warmińsko-Mazurskie } & 2015 & 2.8 & 1.1 & 1.7 & 0.7 & 28.4 & 55.3 \\
\hline & 2000 & 3.3 & 0.6 & 2.0 & 0.4 & 17.1 & 62.0 \\
\hline \multirow{2}{*}{ Wielkopolskie } & 2015 & 1.2 & 0.7 & 1.4 & 0.8 & 43.9 & 65.7 \\
\hline & 2000 & 1.3 & 0.3 & 1.4 & 0.3 & 26.3 & 70.2 \\
\hline \multirow{2}{*}{ Zachodniopomorskie } & 2015 & 7.1 & 1.4 & 5.3 & 1.1 & 19.7 & 50.1 \\
\hline & 2000 & 7.5 & 0.4 & 5.7 & 0.3 & 11.3 & 55.5 \\
\hline \multirow{2}{*}{ POLAND } & 2015 & 1.8 & 0.8 & 2.3 & 1.0 & 37.9 & 66.8 \\
\hline & 2000 & 1.7 & 0.3 & 2.1 & 0.4 & 21.9 & 60.2 \\
\hline
\end{tabular}

Source: Statistics Poland [24, 25]. 


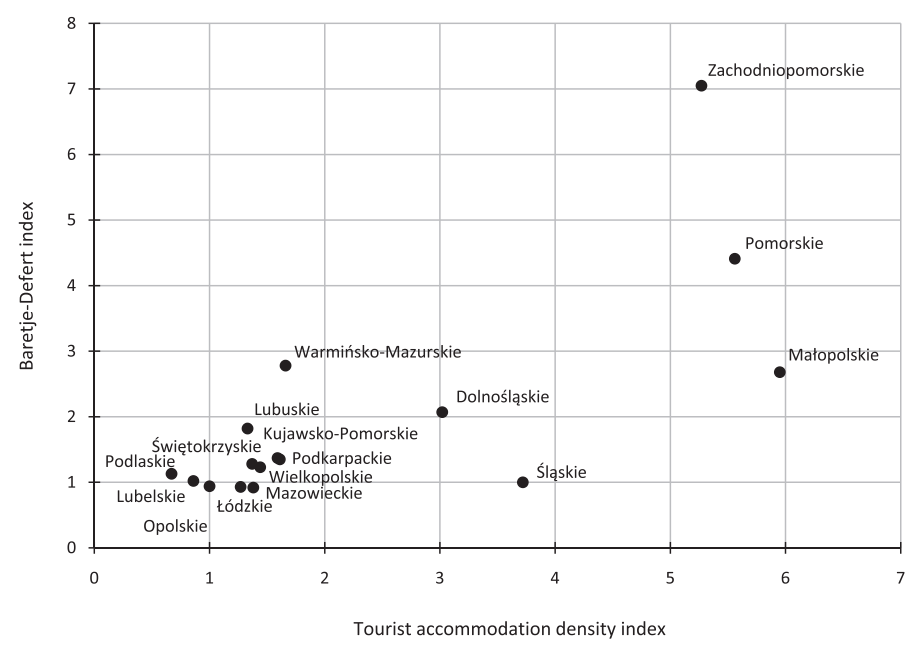

Figure 2. Number of guest beds per 100 inhabitants (Baretje-Defert index) and per $1 \mathrm{~km}^{2}$ (tourist accommodation density index) in Polish provinces in 2015

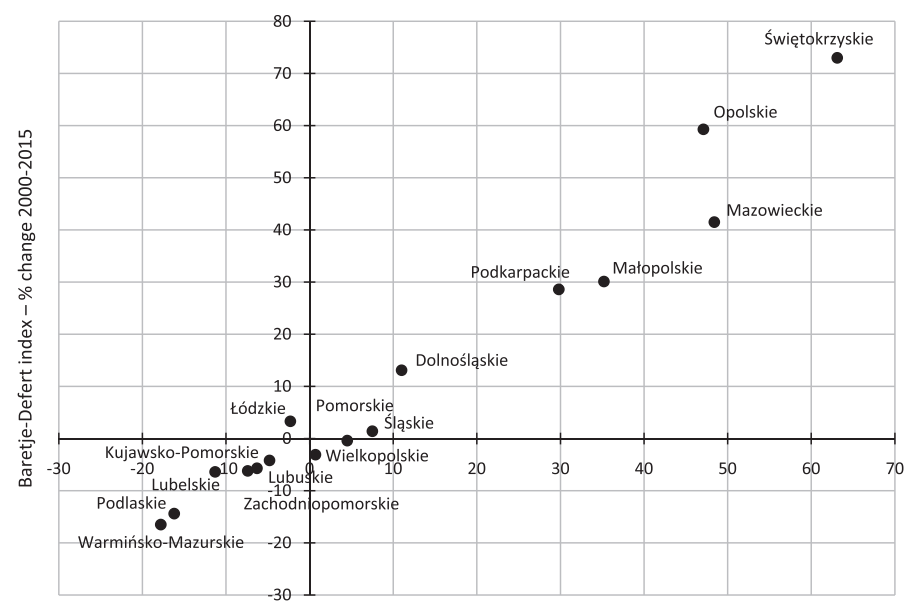

Tourist accommodation density index - \% change 2000-2015

Figure 3. Dynamics of changes in number of guest beds per 100 inhabitants (Baretje-Defert index) and per $1 \mathrm{~km}^{2}$ (tourist accommodation density index) in Polish provinces in 2000-2015

More variation was found in the concentration of tourist accommodation with respect to the surface of the provinces. There was an approximately 8.6-fold difference between extreme values (the Małopolskie Province had 6 guest beds per $1 \mathrm{~km}^{2}$, and the Podlaskie Province had 0.7 bed per $1 \mathrm{~km}^{2}$ ). This measure also showed that 11 provinces had figures below the average one for Poland $\left(2.3\right.$ beds per $1 \mathrm{~km}^{2}$ ). The values for two provinces (the Podlaskie and Lubelskie Provinces) were not even equal to half the national average (Tab. 2).

An analysis of the changes in the tourist accommodation in Poland in the years 2000-2015 (Tab. 2) showed that there was a tendency for growth both in terms of the number of facilities and of guest beds. According to the data of the Polish central statistical office, in 2015, the number of facilities in Poland had risen by $16.2 \%$ with respect to that in 2000 . The dynamics of the growth in the number of guest beds was considerably smaller, and it amounted to $6.3 \%$ in the analogous period. Since the year 2000, the proportion of beds available throughout the entire year exceeded $50 \%$ of all beds available.
In 2015 , as many $69.0 \%$ guest beds were available the whole year.

The changes occurring in tourist accommodation are evidence of shifts in the tourism function of the regions examined. The dynamics of the changes in the tourist accommodation in Poland and in particular provinces is reflected in the values of the Baretje-Defert index and the tourist accommodation density index (Tab. 3, Fig. 3). As shown in Table 3, over the 15 years analysed (2000-2015), the Baretje-Defert index for Poland increased by $6.9 \%$. Growth was also recorded for 8 provinces. This growth varied, and its size was as follows: small in the Sląskie (1.4\%) and Łódzkie (3.3\%) Provinces; considerable in the Dolnośląskie (13.1\%), Podkarpackie (28.6\%), and Małopolskie (30.1\%) Provinces; and the greatest in the Mazowieckie (41.5\%), Opolskie (59.3\%), and Świętokrzyskie (73\%) Provinces (Tab. 3, Fig. 3). The values of this index fell in the remaining provinces to the following extent: below $5 \%$ in the Pomorskie $(0.4 \%)$, Wielkopolskie (3.1\%), and Kujawsko-Pomorskie (4.2\%) Provinces; from 5 to $10 \%$ in the Lubuskie (5.7\%) and Lubelskie (6.4\%) Provinces; and above $10 \%$ in the Podlaskie (14.4\%) and Warmińsko-Mazurskie (16.5\%) Provinces (Tab. 3, Fig. 3).

The tourist accommodation density index also indicated variation in the changes and their dynamics (Tab. 3, Fig. 3). In the period analysed (2000-2015), the index for Poland grew by $6.1 \%$. In nine provinces, growth was found in the value of this indicator, which was small (up to 10\%) in the Wielkopolskie, Pomorskie, Śląskie, and Dolnośląskie Provinces; considerable (approximately 30-35\%) in the Podkarpackie and Małopolskie Provinces; and large (above 45\%) in the Opolskie, Mazowieckie, and Świętokrzyskie Provinces. In the remaining provinces, a decrease was found, amounting to below 5\% in the Łódzkie and Podkarpackie Provinces; $5-10 \%$ in the Lubuskie and Zachodniopomorskie Provinces; and above 10\% in the Lubelskie, Podlaskie, and Warmińsko-Mazurskie Provinces.

The figures presented above were primarily affected by changes in guest bed capacity. In the period analysed (20002015), the number of guest beds grew in nine provinces. The growth observed amounted to approximately 5\% in the Wielkopolskie and Pomorskie Provinces, approximately 10\% in the Śląskie and Dolnośląskie Provinces, and from above 20\% to 50\% in the Podkarpackie, Małopolskie, Opolskie, and Mazowieckie Provinces. The changes were the most dynamic in the Świętokrzyskie Province (63.6\%). In the remaining seven provinces, a decrease in tourist accommodation capacity was found, amounting to less than 5\% in the Łódzkie and KujawskoPomorskie Provinces; from $5 \%$ to $10 \%$ in the Lubuskie, Zachodniopomorskie, and Lubelskie Provinces; and above 10\% in the Podlaskie and Warmińsko-Mazurskie Provinces.

It is worth emphasising the growth found for the Świętokrzyskie Province, whose accommodation capacity increased significantly. Compared to the remaining provinces, it also had the most dynamic increase in the number of tourist accommodation facilities and guest beds (3.8- and 4.2-fold, respectively). It can be surmised that the rate of the development of the tourist accommodation in the Świętokrzyskie Province was due to the dynamic growth of business tourism (connected with the Targi Kielce Exhibition and Congress Centre), which, along with cultural tourism (related to Baltic culture) and health tourism (related to the Busko-Zdrój health resort), generated a considerable proportion of the tourist traffic [27].

The changes found clearly varied depending on the region. Taking into account all the types of guest beds, the provinces could be divided into the following three groups: provinces where in the years 2000-2015 the growth was more considerable than 
the national average growth (the Świętokrzyskie, Mazowieckie, Opolskie, Małopolskie, Podkarpackie, Dolnośląskie, and Śląskie Provinces), those where it was smaller than the national average (the Pomorskie and Wielkopolskie Provinces), and those where the number of guest beds dropped (the Łódzkie, KujawskoPomorskie, Lubuskie, Zachodniopomorskie, Lubelskie, Podlaskie, and Warmińsko-Mazurskie Provinces).

The changes in the structure of tourist accommodation had to do with the transformation of the Polish economy [28]. These changes consisted in an increase in the share of some types of accommodation facilities and a decrease in the proportion of other types, which was mostly related to the process of adaptation to the market economy. What was also relevant in this respect was the changes in the preferred forms of tourism and leisure activities. For this reason, the number of beds available in certain types of facilities grew in a dynamic manner and decreased in others.

The facilities whose share had grown the most radically were hotel facilities, and those whose number fell the most sharply were low-standard accommodation facilities.

In 2015, low-standard facilities included, among others, holiday resorts (1,027 facilities), youth hostels (322), campsites (309), and travel lodges (44). In total, in 2015, there were 1,702 facilities of this type (constituting approximately $17 \%$ of registered tourist accommodation), which offered 177,873 beds (accounting for $25.0 \%$ of all registered guest beds). This figure was almost twice as small as in 2000, when there were 3,222 facilities offering 305,498 beds (that is $37.4 \%$ and $45.7 \%$ of all facilities and beds registered, respectively).

In the period from 2000 to 2015, the most dynamic growth (an approximately 2.5-fold increase) was observed in the number of beds in hotel facilities (hotels, motels, and guest houses), whereas in 2000, hotel facilities accounted for $18.0 \%$ of tourist accommodation, and in 2015, for more than twice as much, that is $42.5 \%$. The absolute figures for 2000 and 2015 were 120,280 and 301,555 guest beds, respectively (Tab. 2). In 15 provinces (that is all provinces apart from the Zachodniopomorskie Province), guest beds in hotel facilities had the greatest share in tourist accommodation; extreme values were found for the Mazowieckie (76.6\%) and Pomorskie (25.7\%) Provinces (Tab. 2).

The Baretje-Defert and tourist accommodation density indices calculated for the hotel facilities in particular provinces (Tab. 3) indicated that the extreme values of the concentration of guest beds with respect to the number of inhabitants differed only 3.5-fold (these were 1.4 for the Zachodniopomorskie Province and 0.4 for the Lubelskie and Opolskie Provinces), and the extreme values with respect to the surface differed as considerably as 9.5-fold (with values of 2.8 for the Małopolskie Province and 0.3 for the Lubelskie and Podlaskie Provinces).

Looking at the changes in guest bed capacity in the years 2000-2015, growth was observed in all of the provinces (Tab. 2). The average increase was 2.5-fold. The most dynamic growth was found in the Swiętokrzyskie (4.2-fold) and Zachodniopomorskie (3.2-fold) Provinces. The provinces that had the most favourable results in this respect were the Łódzkie and Kujawsko-Pomorskie Provinces, where a relatively low decrease in the overall number of guest beds was accompanied by a relatively high increase in hotel beds (2.9 and 2.8-fold, respectively). On the other hand, the situation in the Warmińsko-Mazurskie Province was not favourable, since there was a considerable decrease in the total number of guest beds, with the lowest dynamics of growth in hotel beds in Poland (1.9-fold).
The growth in hotel facilities is a very positive phenomenon. In the period examined, the number of hotel facilities rose from 1,449 to 3,723 (a 2.6-fold increase, by 157\%). As far as particular regions are concerned, in the years 2000-2015, the greatest dynamics of growth in hotel facilities was found for the Swiętokrzyskie (3.8-fold) and Mazowieckie (3.5-fold) Provinces, and the lowest one was observed for the Warmińsko-Mazurskie Province (1.8-fold).

\section{Occupancy of tourist accommodation}

The next measure reflecting the changes in the tourism function is the volume of tourist traffic, which can be determined based on the number of tourists making use of the accommodation available.

In 2015, approximately 26.9 million guests were registered, and there were approximately 71.2 million overnight stays (Tab. 4).

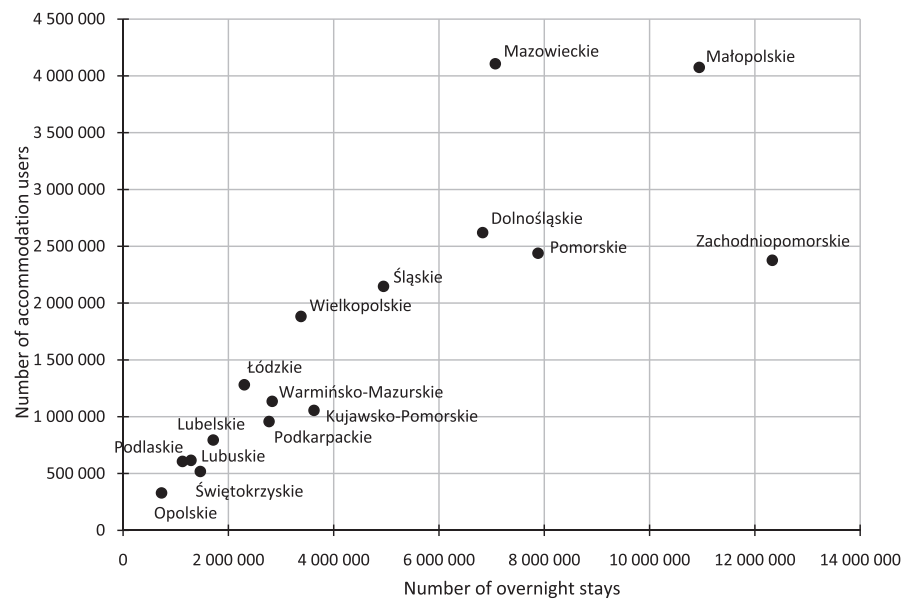

Figure 4. Number of accommodation users and overnight stays in Polish provinces in 2015

The distribution of the tourist traffic varied across the country (Fig. 4). It was the most heavily concentrated in the Mazowieckie and Małopolskie Provinces. In 2015, hotel facilities were used by a total of 4.1 million persons (in total, hotel guests accounted for approximately $30.4 \%$ of all guests who booked accommodation in Poland). Approximately 2.5 million guests were registered in 2015 in the Dolnośląskie, Pomorskie, and Zachodniopomorskie Provinces. The five provinces mentioned above, which offered $59.4 \%$ of the total number of guest beds, received $58 \%$ of all guests recorded by the Polish central statistical office in 2015.

The same five provinces stood out in terms of the number of overnight stays offered (the Zachodniopomorskie, Małopolskie, Pomorskie, Mazowieckie, and Dolnośląskie Provinces). In total, they offered 45 million overnight stays, that is $63.2 \%$ of all stays in Poland.

The average length of stay in the registered hotel facilities in Poland in 2015 was 2.6 days (Tab. 4). In particular provinces, there was relatively large variation in the average time spent at the accommodation by the guests. The longest average length of stay (5.2 days) was found for the Zachodniopomorskie Province, and a relatively long one (lasting more than 3 days) was observed for the Kujawsko-Pomorskie and Pomorskie Provinces. The guests stayed the shortest time (1.71.8 days) in the Mazowieckie, Łódzkie, and Wielkopolskie Provinces (Tab. 4). 
A very important role in providing tourist accommodation was played by hotel facilities; they offered 38.8 million overnight stays, which accounted for $54.5 \%$ of all overnight stays in Poland (Tab. 4).

An analysis of the dynamics of the development of the tourist traffic in Poland over the years 2000-2015 shows that there was a growing trend both in the number of persons using the accommodation and the number of overnight stays (Tab. 4).

According to the data of the Polish central statistical office, by 2015 , the number of persons who used the accommodation (26.9 million) had grown by $84.2 \%$ compared to the year 2000 (14.6 million). This number increased the most in the Mazowieckie and Łódzkie Provinces (by about 150\%) and the least in the Lubuskie Province (28\%).

The rate of the growth of the number of overnight stays booked in the analogous period was almost twice lower and amounted to $45.1 \%$. In absolute numbers, in 2000 and 2015, these figures were 49.1 million and 71.2 million (Tab. 4), respectively, and the greatest, almost two-fold growth was found in the Mazowieckie and Świętokrzyskie Provinces.
During the period analysed (2000-2015), the length of stay at the accommodation facilities changed as well (Tab. 4). In the entire country, the guests' stays became shorter from nearly 3.5 days in 2000 to approximately 2.5 days in 2015 . In 14 provinces (all apart from the Świętokrzyskie and Podkarpackie Provinces), there was a similar trend consisting in the stays becoming shorter. This phenomenon confirms the national trend, which, in turn, reflects the tendency for tourists to travel more often and for shorter periods of time.

The increased importance of hotel facilities in receiving tourists is a highly positive trend. In 2015, they received 20.1 million guests (74.7\% of all guests registered). This was approximately $175 \%$, that is nearly 2.7 times more than in 2000 (Tab. 4), and the greatest increase in this respect (approximately 3.6-fold) was found in the Eódzkie Province. This province had the highest tourist accommodation development index (Tab. 3).

The data examined also indicate a decrease in the interest in low-standard facilities. In the period analysed (2000-2015), there was a drop in the number of overnight stays at travel lodg-

Table 4. Number of accommodation users, number of overnight stays, and average length of stay in Polish provinces in 2000 and 2015

\begin{tabular}{|c|c|c|c|c|c|c|}
\hline \multirow{2}{*}{ Province } & \multirow{2}{*}{ Year } & \multicolumn{2}{|c|}{ Number of accommodation users } & \multicolumn{2}{|c|}{ Number of overnight stays } & \multirow{2}{*}{$\begin{array}{l}\text { Average length } \\
\text { of stay }\end{array}$} \\
\hline & & All facilities & Hotel facilities & All facilities & Hotel facilities & \\
\hline \multirow{2}{*}{ Dolnośląskie } & 2015 & $2,620,400$ & $1,994,000$ & $6,829,700$ & $4,013,900$ & 2.6 \\
\hline & 2000 & $1,526,300$ & 718,400 & $5,525,800$ & $1,536,600$ & 3.6 \\
\hline \multirow{2}{*}{ Kujawsko-Pomorskie } & 2015 & $1,055,500$ & 750,500 & $3,625,500$ & $1,330,900$ & 3.4 \\
\hline & 2000 & 576,300 & 261,800 & $2,286,700$ & 440,300 & 4.0 \\
\hline \multirow{2}{*}{ Lubelskie } & 2015 & 794,400 & 586,400 & $1,711,600$ & 879,900 & 2.2 \\
\hline & 2000 & 516,300 & 208,000 & $1,489,000$ & 374,300 & 2.9 \\
\hline \multirow{2}{*}{ Lubuskie } & 2015 & 615,900 & 466,300 & $1,289,100$ & 716,800 & 2.1 \\
\hline & 2000 & 481,100 & 244,300 & $1,161,800$ & 368,300 & 2.4 \\
\hline \multirow{2}{*}{ Łódzkie } & 2015 & $1,281,100$ & $1,068,500$ & $2,302,000$ & $1,662,000$ & 1.8 \\
\hline & 2000 & 529,900 & 294,400 & $1,457,800$ & 576,900 & 2.8 \\
\hline \multirow{2}{*}{ Małopolskie } & 2015 & $4,075,000$ & $2,944,800$ & $10,942,800$ & $6,452,900$ & 2.7 \\
\hline & 2000 & $1,968,600$ & 962,400 & $6,710,000$ & $2,398,900$ & 3.4 \\
\hline \multirow{2}{*}{ Mazowieckie } & 2015 & $4,107,000$ & $3,742,200$ & $7,069,600$ & $6,153,400$ & 1.7 \\
\hline & 2000 & $1,616,500$ & $1,206,300$ & $3,275,100$ & $2,196,900$ & 2.0 \\
\hline \multirow{2}{*}{ Opolskie } & 2015 & 329,100 & 224,000 & 730,100 & 406,100 & 2.2 \\
\hline & 2000 & 142,400 & 89,900 & 374,700 & 162,500 & 2.6 \\
\hline \multirow{2}{*}{ Podkarpackie } & 2015 & 957,700 & 671,900 & $2,772,600$ & $1,204,800$ & 2.9 \\
\hline & 2000 & 573,400 & 236,800 & $1,430,700$ & 387,700 & 2.5 \\
\hline \multirow{2}{*}{ Podlaskie } & 2015 & 606,500 & 463,700 & $1,281,100$ & 688,700 & 1.9 \\
\hline & 2000 & 390,500 & 149,400 & 921,300 & 248,400 & 2.4 \\
\hline \multirow{2}{*}{ Pomorskie } & 2015 & $2,439,200$ & $1,575,300$ & $7,880,500$ & $3,425,500$ & 3.2 \\
\hline & 2000 & $1,312,500$ & 535,200 & $5,801,300$ & $1,111,800$ & 4.4 \\
\hline \multirow{2}{*}{ Śląskie } & 2015 & $2,147,400$ & $1,619,800$ & $4,945,700$ & $3,042,400$ & 2.3 \\
\hline & 2000 & $1,295,000$ & 645,800 & $3,323,000$ & $1,406,100$ & 2.6 \\
\hline \multirow{2}{*}{ Świętokrzyskie } & 2015 & 518,100 & 420,200 & $1,466,800$ & 796,200 & 2.8 \\
\hline & 2000 & 264,400 & 142,200 & 697,700 & 266,100 & 2.6 \\
\hline \multirow{2}{*}{ Warmińsko-Mazurskie } & 2015 & $1,135,000$ & 889,700 & $2,831,900$ & $1,794,100$ & 2.5 \\
\hline & 2000 & 835,500 & 536,100 & $2,281,900$ & 964,000 & 2.7 \\
\hline \multirow{2}{*}{ Wielkopolskie } & 2015 & $1,882,700$ & $1,497,200$ & $3,378,300$ & $2,380,900$ & 1.8 \\
\hline & 2000 & $1,125,000$ & 597,200 & $2,655,200$ & 976,400 & 2.4 \\
\hline \multirow{2}{*}{ Zachodniopomorskie } & 2015 & $2,377,200$ & $1,221,200$ & $12,330,100$ & $3,856,500$ & 5.2 \\
\hline & 2000 & $1,474,200$ & 417,900 & $9,686,800$ & 882,000 & 6.6 \\
\hline \multirow{2}{*}{ POLAND } & 2015 & $26,942,100$ & $20,135,800$ & $71,234,400$ & $38,804,800$ & 2.6 \\
\hline & 2000 & $14,627,900$ & $7,246,100$ & $49,078,800$ & $14,297,200$ & 3.4 \\
\hline
\end{tabular}

Source: Statistics Poland [24, 25]. 
es of $58.4 \%$, at holiday resorts of $34.0 \%$, at campsites of $14.9 \%$, and at youth hostels of $6.8 \%$.

\section{Degree and nature of changes in tourism function}

The tourism function is generally associated with regions which are attractive for tourists for specific reasons. In such areas, tourism is one of the most important forms of social and economic activity. This activity is focused on satisfying the broadly understood cognitive and leisure-related needs of tourists visiting a given area.

The number of persons staying at the tourist accommodation and the number of overnight stays relative to the number of inhabitants were used to calculate the Schneider and Charvat indices. On the other hand, the number of persons using the accommodation with respect to the surface was used to calculate the Defert index. These indices, which measure the level of the development of the tourism function, confirmed that a process of change had occurred in the tourism function in Poland and its particular provinces. Moreover, apart from factors related to the location of the province (the environment and cultural her- itage), they are among the basic tools used in the evaluation of the competitiveness of regions [2].

In 2000, the Schneider index in Poland was 37.8, and by the year 2015, it had grown two-fold and attained the value of 70.1. This corresponds with the number of 38 and 70 tourists making use of the accommodation per 100 inhabitants (Tab. 5).

In 2015, the Schneider index was found to have values above the average for Poland (70.1) in six provinces: the Mazowieckie (76.8), Warmińsko-Mazurskie (78.8), Dolnośląskie (90.2), Pomorskie (105.7), Małopolskie (120.8), and Zachodniopomorskie (139) Provinces. In the remaining ten provinces, the values of the index were lower, and the lowest values were found for the Opolskie (33.0) and Lubelskie (37.1) Provinces (Tab. 5, Fig. 5).

Over 15 years (2000-2015), the Schneider index for Poland increased by approximately $85 \%$. In particular provinces, the increase observed varied. Growth exceeding 100\% characterised the Świętokrzyskie (106.2), Mazowieckie (140.9), Opolskie (151.8), and Łódzkie (156.3) Provinces. The smallest growth was noted in the Warmińsko-Mazurskie (38.6) and Lubuskie (29.6) Provinces, with the figures amounting to $30-40 \%$ (Fig. 6).

Table 5. Indices measuring tourist traffic volume in Polish provinces in 2000 and 2015

\begin{tabular}{|c|c|c|c|c|c|c|c|}
\hline \multirow{2}{*}{ Province } & \multirow{2}{*}{ Year } & \multicolumn{2}{|c|}{ Schneider index } & \multicolumn{2}{|c|}{ Charvat index } & \multicolumn{2}{|c|}{ Defert index } \\
\hline & & All facilities & Hotel facilities & All facilities & Hotel facilities & All facilities & Hotel facilities \\
\hline \multirow{2}{*}{ Dolnośląskie } & 2015 & 90.2 & 68.6 & 235.2 & 138.2 & 131.4 & 100.0 \\
\hline & 2000 & 51.3 & 24.2 & 185.9 & 51.7 & 76.5 & 36.0 \\
\hline \multirow{2}{*}{ Kujawsko-Pomorskie } & 2015 & 50.6 & 36.0 & 173.8 & 63.8 & 58.7 & 41.8 \\
\hline & 2000 & 27.4 & 12.5 & 108.9 & 21.0 & 32.1 & 14.6 \\
\hline \multirow{2}{*}{ Lubelskie } & 2015 & 37.1 & 27.4 & 80.0 & 41.1 & 31.6 & 23.3 \\
\hline & 2000 & 23.1 & 9.3 & 66.7 & 16.8 & 20.6 & 8.3 \\
\hline \multirow{2}{*}{ Lubuskie } & 2015 & 60.9 & 45.8 & 126.6 & 70.4 & 44.0 & 33.3 \\
\hline & 2000 & 47.0 & 23.8 & 113.5 & 36.0 & 34.4 & 17.5 \\
\hline \multirow{2}{*}{ Łódzkie } & 2015 & 51.4 & 42.8 & 92.3 & 66.6 & 70.3 & 58.6 \\
\hline & 2000 & 20.0 & 11.1 & 55.2 & 21.8 & 29.1 & 16.2 \\
\hline \multirow{2}{*}{ Małopolskie } & 2015 & 120.8 & 87.3 & 324.5 & 191.3 & 268.4 & 194.0 \\
\hline & 2000 & 60.9 & 29.8 & 207.5 & 74.2 & 130.0 & 63.5 \\
\hline \multirow{2}{*}{ Mazowieckie } & 2015 & 76.8 & 70.0 & 132.2 & 115.0 & 115.5 & 105.2 \\
\hline & 2000 & 31.9 & 23.8 & 64.6 & 43.3 & 45.4 & 33.9 \\
\hline \multirow{2}{*}{ Opolskie } & 2015 & 33.0 & 23.2 & 73.3 & 42.0 & 35.0 & 23.8 \\
\hline & 2000 & 13.1 & 8.3 & 34.6 & 15.0 & 15.2 & 9.6 \\
\hline \multirow{2}{*}{ Podkarpackie } & 2015 & 45.0 & 31.6 & 130.3 & 56.6 & 53.7 & 37.6 \\
\hline & 2000 & 26.9 & 11.1 & 67.2 & 18.2 & 32.0 & 13.2 \\
\hline \multirow{2}{*}{ Podlaskie } & 2015 & 51.0 & 39.0 & 94.9 & 57.9 & 30.0 & 23.0 \\
\hline & 2000 & 32.0 & 12.3 & 75.5 & 20.5 & 19.4 & 7.4 \\
\hline \multirow{2}{*}{ Pomorskie } & 2015 & 105.7 & 68.3 & 341.5 & 148.4 & 133.2 & 86.0 \\
\hline & 2000 & 59.7 & 24.3 & 263.9 & 50.6 & 71.8 & 29.2 \\
\hline \multirow{2}{*}{ Śląskie } & 2015 & 47.0 & 35.4 & 108.2 & 66.6 & 174.1 & 131.3 \\
\hline & 2000 & 26.7 & 13.3 & 68.6 & 29.0 & 105.3 & 52.5 \\
\hline \multirow{2}{*}{ Świętokrzyskie } & 2015 & 41.2 & 33.4 & 116.7 & 63.3 & 44.2 & 35.9 \\
\hline & 2000 & 20.0 & 10.7 & 52.7 & 20.1 & 22.6 & 12.2 \\
\hline \multirow{2}{*}{ Warmińsko-Mazurskie } & 2015 & 78.8 & 61.8 & 196.7 & 124.6 & 47.0 & 36.8 \\
\hline & 2000 & 56.9 & 36.5 & 155.4 & 65.6 & 34.5 & 22.2 \\
\hline \multirow{2}{*}{ Wielkopolskie } & 2015 & 54.2 & 43.1 & 97.2 & 68.5 & 63.1 & 50.2 \\
\hline & 2000 & 33.5 & 17.8 & 79.0 & 29.0 & 37.7 & 20.0 \\
\hline \multirow{2}{*}{ Zachodniopomorskie } & 2015 & 139.0 & 71.4 & 720.9 & 225.5 & 103.8 & 53.3 \\
\hline & 2000 & 85.0 & 24.1 & 558.7 & 50.9 & 64.4 & 18.2 \\
\hline \multirow{2}{*}{ POLAND } & 2015 & 70.1 & 52.4 & 185.3 & 101.0 & 86.2 & 64.4 \\
\hline & 2000 & 37.8 & 18.8 & 127.0 & 37.0 & 46.8 & 23.2 \\
\hline
\end{tabular}

Source: Statistics Poland [24, 25]. 


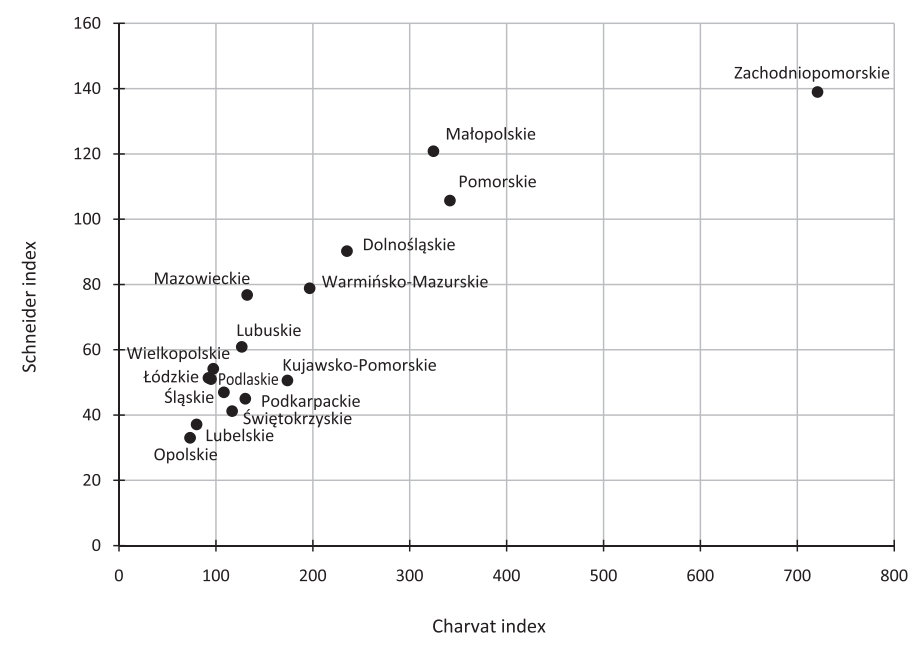

Figure 5. Schneider and Charvat indices of tourism function development in Polish provinces in 2015

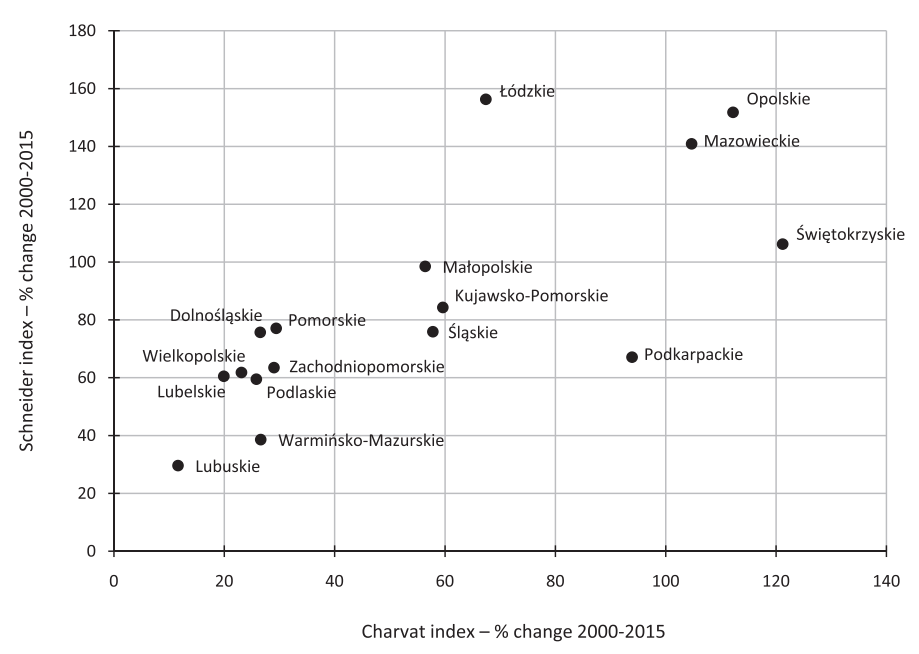

Figure 6. Dynamics of changes in tourist traffic volume in Polish provinces in 2000-2015, represented by the number of tourists per 100 inhabitants (Schneider index) and the number of overnight stays per 100 inhabitants (Charvat index)

In 2000, the Charvat index was equal to 127.0, and in 2015, it exceeded 185.3, meaning that there were approximately 127 and 185 overnight stays per 100 inhabitants (Tab. 5). In 2015, this index was above the average value in the following five provinces: the Warmińsko-Mazurskie (196.7), Dolnośląskie (235.2), Małopolskie (324.5), Pomorskie (341.5), and Zachodniopomorskie (720.9) Provinces. In the remaining eleven provinces, the values of the index were lower, and extreme values were observed for the Opolskie (73.3) and Lubelskie (80.0) Provinces (Tab. 5, Fig. 5).

During the 15-year period analysed, the Charvat index for Poland grew by approximately 46\%. Increases exceeding 100\% were found for the Mazowieckie (104.7), Opolskie (112.2), and Świętokrzyskie (121.2) Provinces, and the smallest one, no larger than 20\%, was noted in the Lubuskie (11.6) and Lubelskie (19.9) Provinces (Fig. 6).

The third index analysed, which reflects the level of the volume of tourist traffic, the Defert index, amounted to 46.8 in 2000 and 86.2 in 2015, that is 47 and 86 guests per $1 \mathrm{~km}^{2}$, in Poland (Tab. 5). In 2015, the following six provinces had index values exceeding 86.2: the Mazowieckie (115.5), Zachodniopomorskie (103.8), Pomorskie (133.2), Dolnośląskie (131.4), Śląskie (174.1), and Małopolskie (268.4) Provinces. In the remaining ten provinces, the values of the index were lower, and extreme values below 40 were observed for the Podlaskie (30.0), Lubelskie (31.6), and Opolskie (35.0) Provinces (Tab. 5).

During a period of 15 years (2000-2015), the Defert index for Poland increased by approximately $84 \%$, which is a similar change as was the case with the Schneider index. In particular provinces, the increase varied. Growth exceeding 100\% characterised the Małopolskie (106.4), Opolskie (130.7), Łódzkie (141.7), and Mazowieckie (154.2) Provinces. The smallest growth was found in the Warmińsko-Mazurskie (36.0) and Lubuskie (28.0) Provinces, with increases amounting to 30-40\%.

Looking at the results obtained, it can be observed that the areas which were the most competitive (that had high levels of tourism function indicators) were those located in south and north Poland (Fig. 7). They were characterised by a high level of tourist accommodation capacity (Fig. 7ABC) and tourist traffic in the accommodation (Fig. 7DEF). The Małopolskie and Dolnośląskie as well as the Zachodniopomorskie and Pomorskie Provinces were visited the most frequently by tourists. The provinces also had well-developed tourist accommodation (Fig. 7).

The Małopolskie and Dolnośląskie Provinces stood out in terms of their rich natural and cultural resources (Fig. 8). In both provinces, the capital cities, that is Kraków and Wrocław, were the key assets [29].

The Pomorskie and Zachodniopomorskie Provinces had relatively rich resources having to do with broadening tourists' knowledge about the country and particular regions, especially the Tricity (Gdańsk, Gdynia, and Sopot) metropolitan area, followed by Szczecin and Kołobrzeg. They also had large recreation potential (Fig. 8). However, these areas had issues connected with the fact that tourist activity in the narrow area adjacent to the Baltic Sea and lake areas is seasonal [29].

One of the leading positions among Polish provinces was also occupied by the Mazowieckie Province, which the province owed nearly exclusively to the Warsaw agglomeration, a centre for culture, art, science, business, and government. Cultural resources were particularly important in this province (Fig. 8).

What constitutes a clearly different segment is provinces with less well developed, but, at the same time, less seasonal tourism, such as the Wielkopolskie, Łódzkie, Śląskie, Świętokrzyskie, Lubelskie, Podkarpackie, and KujawskoPomorskie Provinces. Their advantage lay in the presence of urban agglomerations (the Łódzkie and Wielkopolskie Provinces) and the combination of cultural and natural resources (the Świętokrzyskie, Lubelskie, Podkarpackie, and KujawskoPomorskie Provinces).

A special position was held by the Opolskie, Lubuskie, and Warmińsko-Mazurskie Provinces [29]. The Opolskie Province, which remained in the shadow of the Upper Silesia and Wrocław conurbations, had the smallest accommodation capacity and was visited by the lowest number of tourists. A province that had a similar feature was the Lubuskie Province, which lies near the border the Germany, on a transit route, half way between the cities of Poznań and Wrocław and Berlin. On the other hand, the Warmińsko-Mazurskie Province was for years regarded as one of the key regions for tourism. Nowadays, its position on the market is considerably worse. Not only does this province not have a strong agglomeration, but it also struggles with issues having to do with the seasonal nature of its tourist traffic to a greater extent than the Pomorskie and Zachodniopomorskie Provinces. 

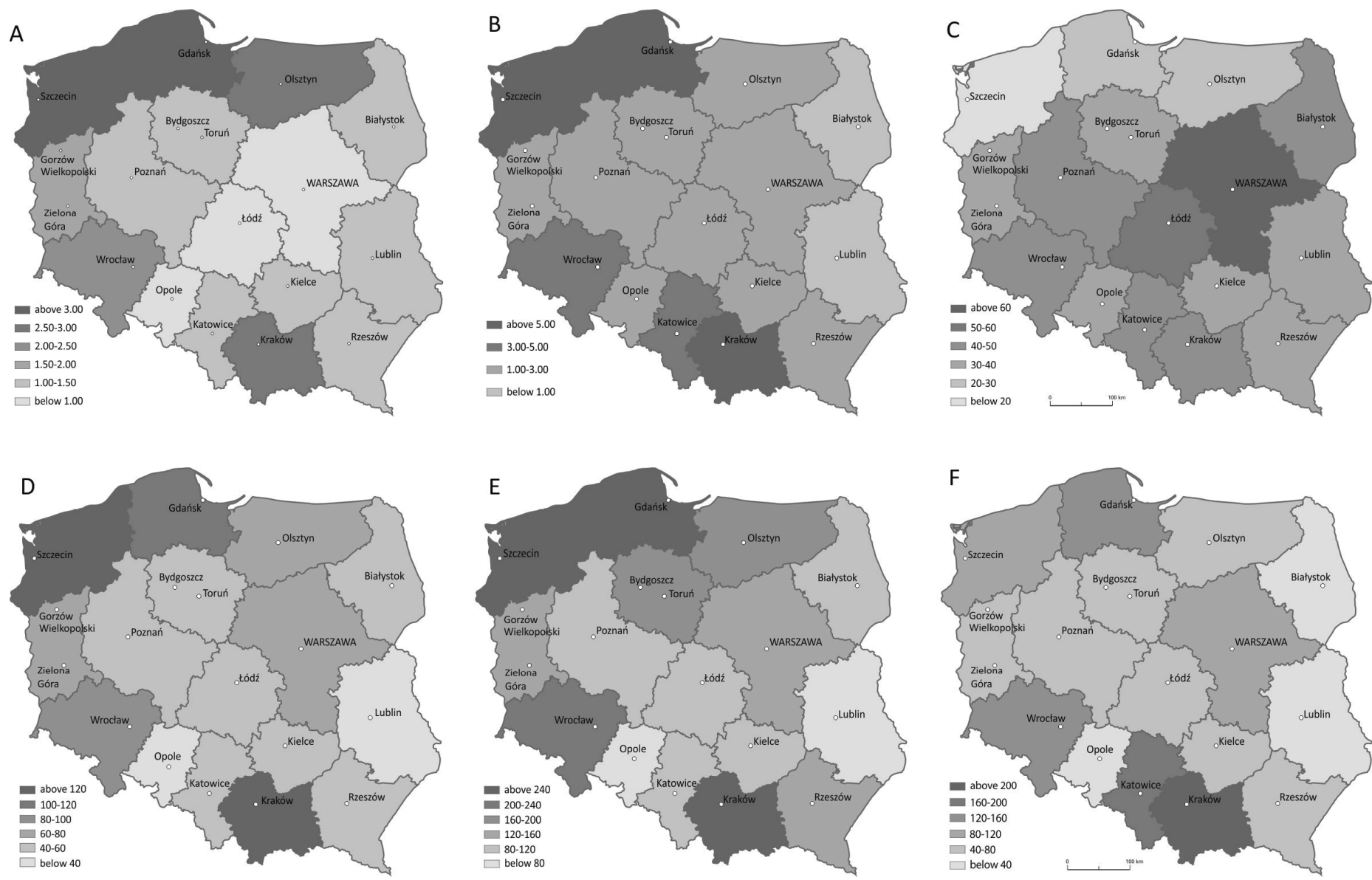

Figure 7. Spatial variation in the values of the Baretje-Defert (A), tourist accommodation density (B), tourist accommodation development (C), Schneider (D), Charvat (E), and Defert (F) indices for Polish provinces in 2015

\section{Conclusions}

The assessment of the tourism function of Polish provinces with respect to the situation in Poland is relative. The level of the development of this function examined on the basis of tourist accommodation capacity and the volume of tourist traffic, analysed based on the number of persons using the accommodation, varied in terms of time and space. The indices calculated made it possible to determine the competitive advantage, which stemmed from the resources and infrastructure used by tourists and the features of the competitive environment. At the same time, they reflect the capacity of a region to attract tourists and to continually develop the tourism function while being in competition with other regions. According to the results of the study, the situation is the most favourable in the Zachodniopomorskie, Pomorskie, Mazowieckie, and Małopolskie Provinces.

The Zachodniopomorskie Province, which constitutes $7.3 \%$ of the surface of Poland and is inhabited by $4.4 \%$ of the country's population, stands out from among all provinces in terms of the number of beds available to tourists registered by the Polish central statistical office (17\% of the guest bed capacity in the entire country). The occupancy of the tourist accommodation puts the province the highest in the ranking. In 2015, the greatest number of overnight stays were booked there $(17.3 \%)$, and, moreover, the average length of the stays at the facilities was the longest (approximately 5.2 days). It is for the Zachodniopomorskie Province that the highest values of the Schneider (139) and Charvat (721) indices were obtained. The number of tourists who made use of the accommodation relative to the number of guest beds available, that is the tourist accommodation development index, had the lowest value for this province (below 20). In terms of the types of accommodation available, the province is characterised by the smallest share of hotel facilities (19.5\%) and of guest beds in hotel facilities (20.2\%). The Zachodniopomorskie Province is also distinct in that it has the smallest share of guests $(51.4 \%)$ and overnight stays (31.3\%) in hotel facilities.

The Pomorskie Province, which accounts for $5.9 \%$ of the surface of Poland and is inhabited by $6 \%$ of the population, is characterised by the greatest capacity of the accommodation facilities among all the provinces (15.1\% in 2015). The values of the indices characterising the capacity of the guest beds give this province the second place in the ranking, after the Zachodniopomorskie Province, when it comes to the Baretje-Defert index (4.4), and the second place, after the Małopolskie Province, in terms of the tourist accommodation density index (5.6). This rich offer of accommodation facilities is used by a relatively large number of tourists, since the province is 4 th in the ranking with respect to the number of persons using the accommodation, with a share of $9.1 \%$. The value of the tourist accommodation development index, similarly as is the case with the Zachodniopomorskie Province, is among the lowest ones (24.0). Together 
with the Zachodniopomorskie Province, the Pomorskie Province has the lowest position in the ranking in terms of the share of accommodation facilities and that of guest beds in hotel facilities, with values amounting to $21.1 \%$ and $25.7 \%$, respectively, as well as the share of persons using this type of accommodation (64.6\%). Taking into account its share of overnight stays in hotel facilities $(43.5 \%)$, the Pomorskie Province only has a higher figure than the Zachodniopomorskie (31.3\%) and KujawskoPomorskie (36.7\%) Provinces.

The Mazowieckie Province, which is the largest province in Poland (occupying $11.4 \%$ of its surface) has the greatest population (13.9\%). It stands out from the provinces in terms of the greatest concentration of tourist traffic. In 2015, the greatest percentage of persons making use of hotel facilities was found in this province (15.2\%). It also leads the ranking with respect to the number of overnight stays offered: it occupies the 4th place, with a share of 9.9\%, after the Zachodniopomorskie, Małopolskie, and Pomorskie Provinces. The tourist accom- modation development index, which is the number of tourists making use of the accommodation relative to the number of guest beds, attained a value of 83.9, which was the highest value in the country. At the same time, the Mazowieckie Province is distinct in terms of having the shortest average length of stay at the accommodation (1.7 days). The data from 2000 and 2015 indicate that the province is characterised by the most dynamic change in the number of guests using the accommodation (an increase of $154.1 \%$ ) and of overnight stays (by 115.8\%). Moreover, it stands out in terms of the share of hotel facilities in the accommodation capacity (63.4\%) and the highest share of guest beds in hotel facilities (76.6\%). The Mazowieckie Province has the largest share of guests staying at hotel facilities $(91.1 \%)$ and the highest proportion (87.0\%) of overnight stays at those facilities.

The Małopolskie Province, which has a surface constituting $4.9 \%$ of that of Poland and is inhabited by $8.8 \%$ of the country's population, is characterised by a relatively large share of

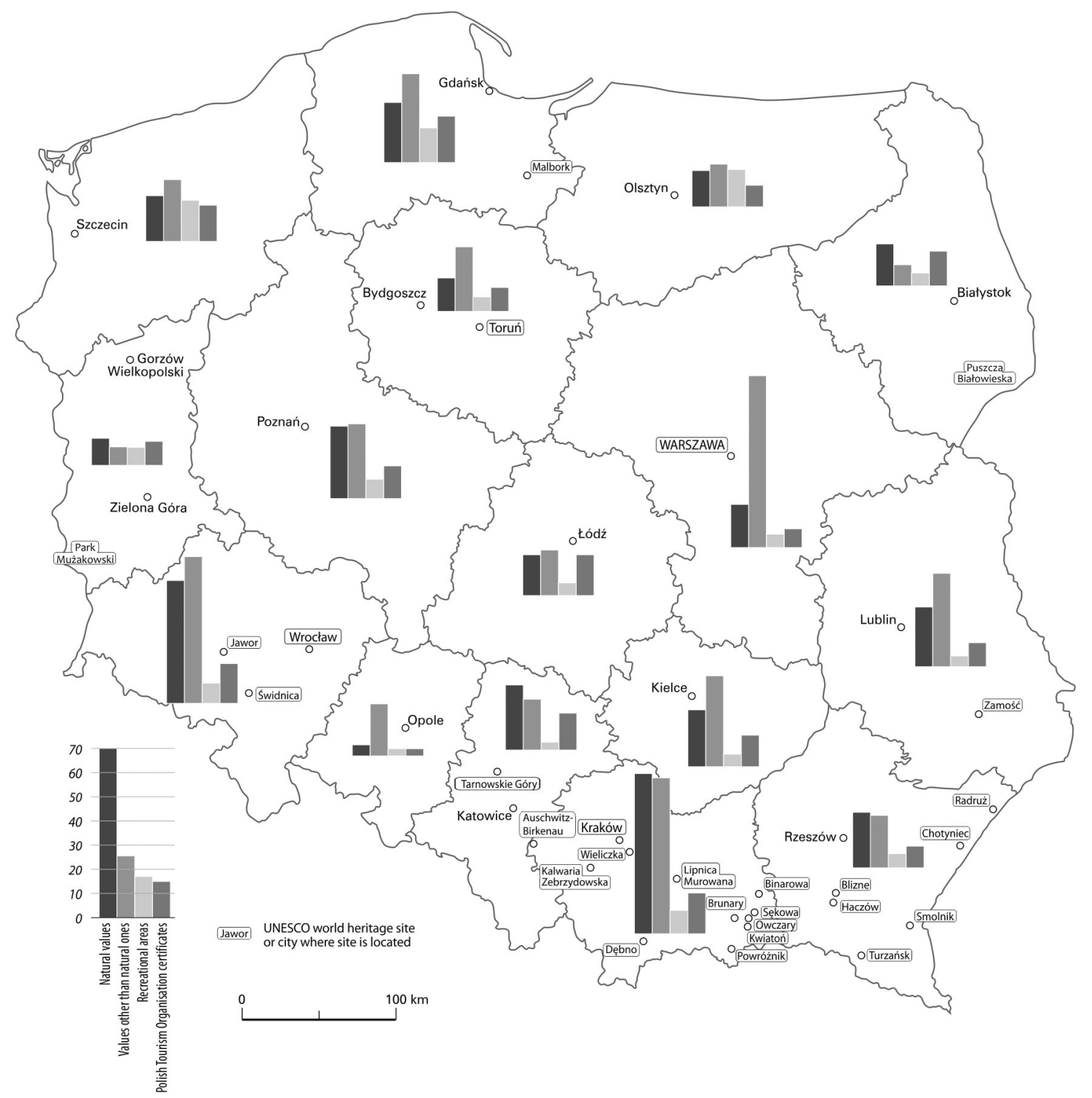

Figure 8. Selected determinants of the attractiveness of Polish provinces for tourists (based on Lijewski et al. [30] and https://polskapodajdalej.pl/pl/ [31]) 
accommodation facilities and guest beds, after the provinces located near the Baltic Sea. In terms of the number of facilities (14.4\% of the capacity of the country), it is second in the ranking, following the Pomorskie Province, and with respect to the number of guest beds offered (12.7\%), it occupies the third place, after the Zachodniopomorskie and Pomorskie Provinces. Its large potential in this respect is reflected in the tourist accommodation density index (6.0, which was the highest value observed) and the Baretje-Defert index (2.7). In terms of the number of guests using the accommodation, the Małopolskie Province (with a share of $15.1 \%$ ) is second only to the Mazowieckie Province (15.2\%), but the difference between the two is minimal. This region also holds a high place in the ranking with regard to the number of overnight stays $(15.4 \%$, which gives it second place after the Zachodniopomorskie Province). The numerical values of the indices which give the province a high position in the ranking - that is a Defert index of 268.4 (1st place in the ranking), a Schneider index of 120.8 (2nd position), and a Charvat index of 324.5 (3rd position) - reflect the high volume of tourist traffic in this area.

According to the results of the study, the provinces which have the lowest accommodation capacity are the Lubelskie and Opolskie Provinces. The values of the indices calculated for these provinces typically put them in the bottom part of the ranking. The second-to-last province in the ranking is the Lubelskie Province, which occupies $8.0 \%$ of the surface of the country and is inhabited by $5.6 \%$ of the population. In the case of the values of as many as five indicators - the Baretje-Defert index, the tourist accommodation density index, as well as the Schneider, Charvat, and Defert indices - the region has scores clearly below the average values for the whole country. It is only for the tourist accommodation development index that the value for this province (36.4) is similar to the national average (37.9).

The least favourable results with respect to the development of the tourism function were recorded for the Opolskie Province, which is the smallest province in the country (occupying 3\% of its surface) and has the smallest number of inhabitants $(2.5 \%)$. This province has only a $1.7 \%$ share in the accommodation capacity of the facilities in Poland, a $1.3 \%$ share in the capacity of guest beds, a $1.2 \%$ share in the number of guests, and a $1.0 \%$ share in the number of overnight stays. The lowest values of the following indices in the country were recorded for this province: the Baretje-Defert (0.9), Schneider (33.0), Charvat (73.3), and Defert (35.0) indices. Similarly as was the case with the Lubelskie Province, only the tourist accommodation development index, calculated as the number of persons using the accommodation relative to the number of guest beds, had a value similar to the national average (35.0).

To sum up, competitiveness is the capacity of fulfil one's aims on a competitive market by attracting a particular group of tourists/clients. In Poland, a greater level of the development of the tourism function characterises regions of high natural and cultural value; this value, however, is not always sufficient for ensuring a high concentration of tourist accommodation and traffic.

At the same time, it should be borne in mind that provinces are such large units that in diagnosing, representing, and analysing the dynamics and directions of the changes in the tourism function, we have had to make broad generalisations. Tourism has a tendency to concentrate in smaller units, such as cities, communes, and, more rarely, districts. The analyses conducted in the current study can serve as a point of departure for further, detailed studies covering smaller administrative units.

\section{Literature}

1. Gołembski G. (ed.) (2008). Tourism as a regional competitiveness growth factor in the era of globalisation. Poznań: Wydawnictwo Akademii Ekonomicznej w Poznaniu. [in Polish]

2. Grabowski J. (2008). Determinants of the competitiveness of tourist regions. Ruch prawniczy, ekonomiczny $i$ socjologiczny 70(3), 149-164. [in Polish]

3. Panfiluk E. (2011). Determinants and barriers related to the competitive advantage of valuable nature areas based on the example of the micro-region of the Białowieża Forest. In A. Rapacz (ed.), Tourism economy in a region. Business. Self-government. Cooperation (pp. 313-328). Wrocław: Wydawnictwo Akademii Ekonomicznej. [in Polish]

4. Mika M. (2014). Premises and determinants of the sustainability of local tourism development. Kraków: Instytut Geografii i Gospodarki Przestrzennej UJ. [in Polish]

5. Włodarczyk B. (2006). Tourism space - Cyclicality, actors, and factors determining development. Turyzm 16(2), 41-64. [in Polish]

6. Janowski I. (1995). Environmental conditions and functions of tourism. Katowice: Wydawnictwo Śląsk. [in Polish]

7. Kiniorska I., Partyka S. (2017). Tourism function as a stimulating factor for the towns and cities of the Swiętokrzyskie Province. Ekonomiczne Problemy Turystyki 2(38), 157-167. [in Polish]

8. Matczak A. (1989). Issues in investigating the tourism function of Polish cities. Acta Universitatis Lodziensis. Turyzm 5, 27-39. [in Polish]

9. Fischbach J. (1989). Tourism function of spatial entities. Acta Universitatis Lodziensis. Turyzm 5, 7-26. [in Polish]

10. Derek M. (2008). Tourism function as a factor of local development in Poland. Warsaw: Wydział Geografii i Studiów Regionalnych UW. [in Polish]

11. Pytel S. (2010). The role of cultural tourism in the development of the municipalities of the Sląskie Province. Landscape and tourism. Prace Komisji Krajobrazu Kulturowego 14, 273-282. [in Polish]

12. Gołembski G. (ed.) (2011). Measurement methods and determinants of the tourism function of cities: The case of Poznań. Poznań: Wyd. Uniwersytetu Ekonomicznego w Poznaniu. [in Polish]

13. Więcław-Michniewska J. (2011). Selected determinants of the tourism function of towns in the Polish Carpathians. Prace Geograficzne 125, 176-196. [in Polish]

14. Szromek A.R. (2012). Tourism function indices. The concept of a tourism and health function index. Gliwice: Wydawnictwo Politechniki Śląskiej. [in Polish]

15. Durydiwka M. (2012). Determinants of the development of the tourism function in rural areas in Poland and its diversity. Warsaw: Wydział Geografii i Studiów Regionalnych UW. [in Polish]

16. Durydiwka M. (2015). The tourism function of rural areas in the Pomorskie Province: Diversity and change. Turyzm 25(1), 39-45. [in Polish]

17. Piotrowski J. (2015). Changes in the tourism function of the tourist regions of the Śląskie Province. Studia Ekonomiczne. Zeszyty Naukowe Uniwersytetu Ekonomicznego w Katowicach 215, 57-73. [in Polish]

18. Warszyńska J. (1985). Tourism function of the Polish Carpathian Mountains. Studia Geographica. Series GeographicaOeconomica 18, 79-104. [in Polish]

19. Chudy-Hyski D. (2006). Assessment of selected determinants of the tourism function of a geographical area. Infra- 
struktura i Ekologia Terenów Wiejskich 2(1), 129-141. [in Polish]

20. Żek M. (2008). The tourism function of the Bug River area. Turystyka i Hotelarstwo 14, 67-80. [in Polish]

21. Krukowska R. (2009). The Łęczyńsko-Włodawskie Lake District - Tourism function of the region. Folia Turistica 21, 165-184. [in Polish]

22. Majewska J. (2011). The measurement and evaluation of tourism development in Polish cities in the last decade: A comparison of Poznan with other large cities in Poland. In G. Gołembski (ed.), Measurement methods and determinants of the tourism function of cities: The case of Poznan (pp. 36-65). Poznań: Wyd. Uniwersytetu Ekonomicznego w Poznaniu. [in Polish]

23. Spychała A., Graja-Zwolińska S. (2011). Dynamics and nature of changes in the tourism function of the Wielkopolskie Province in the years 1995-2009. In B. Krakowiak, J. Latosińska (eds), Workshop in tourism geography. Tourism in Poland in the years 1989-2009 (pp. 81-91). Łódź: Wydawnictwo UŁ. [in Polish]

24. Statistics Poland (GUS). (2001). Statistical yearbook of Polish provinces. Warsaw. [in Polish]

25. Statistics Poland (GUS). (2016). Statistical yearbook of Polish provinces. Warsaw. [in Polish]
26. Meyer B., Panasiuk A., Sawińska A. (2013). Tourist accommodation as a factor in creating the "Pomeranian Way of St. James" tourist product in the Zachodniopomorskie Province. Ekonomiczne Problemy Turystyki 4(24), 131-145. [in Polish]

27. Pałka-Łebek E., Wrońska-Kiczor J. (2017). Role and importance of clusters in the development of tourism in the Swiętokrzyskie Voivodship. Ekonomiczne Problemy Turystyki 2(38), 181-189. [in Polish]

28. Rogacki H. (2009). Dynamics and structural transformation of the tourist accommodation in Poland: A regional approach. Folia Turistica 21, 203-220. [in Polish]

29. Kozak M. (2009). Tourism and tourism policy: Between an old and new paradigm. Warsaw: Wydawnictwo Naukowe Scholar. [in Polish]

30. Lijewski T., Mikułowski B., Wyrzykowski J. (2008). The geography of tourism in Poland. Warsaw: Polskie Wydawnictwo Ekonomiczne.

31. Polska Organizacja Turystyczna. (2018). https://polskapodajdalej.pl/pl/ Retrieved on 16.02.2018. [in Polish]

Submitted: March 12, 2018

Accepted: April 27, 2018 